MONIKA KOZŁOWSKA

\title{
RYNEK OBROTU NIERUCHOMOŚCIAMI W BIALYMSTOKU W XVIII WIEKU
}

DOI: $10.15290 /$ sp.2017.25.05

\begin{abstract}
Abstrakt. Artykuł przedstawia wyniki analiz funkcjonowania rynku obrotu nieruchomościami w Białymstoku w drugiej połowie XVIII w. Materiałem źródłowym, na którym oparto badania są najstarsze zachowane księgi miejskie Białegostoku z lat 1740-1795. Obserwacji poddano takie elementy, jak: strukturę i wielkość obrotów, ceny i rodzaj nieruchomości oraz strukturę społeczną osób dokonujących transakcji.
\end{abstract}

Słowa kluczowe: Białystok, rynek nieruchomości, historia społeczno-gospodarcza

\begin{abstract}
The article presents the outcomes of the analysed operation of the real estate market in Bialystok in the second half of the 18th century. The research has been based on the oldest preserved Bialystok city records from 1740-1795. The following elements have been explored: the structure and value of sales, real estates' prices and types, and a social structure of purchasers and sellers.
\end{abstract}

Key words: Bialystok, real estate market, socioeconomic history

Przedstawione $\mathrm{w}$ niniejszym artykule rozważania stanowią próbę analizy jednego z aspektów aktywności gospodarczej mieszczan białostockich, jakimi były transakcje kupna-sprzedaży nieruchomości $\mathrm{w}$ drugiej połowie XVIII w. Studia nad rynkiem nieruchomości - obok badania życia kredytowego - stanowią jeden z podstawowych sposobów poznania kondycji ekonomicznej mieszczan oraz społeczno-gospodarczej sytuacji miasta. Analiza struktury i wielkości obrotów, zasięgu społecznego (udziału w rynku chrześcijan, Żydów, kobiet), cen oraz rodzajów nieruchomości pozwoli jeszcze szerzej zarysować życie ekonomiczne społeczności szczególnie charakterystycznego dla dawnej Rzeczypospolitej typu ośrodka miejskiego - małego prywatnego miasta.

Materiałem źródłowym, na którym oparto analizę są białostockie księgi miejskie, zawierające wpisy z lat 1740-1795¹. Do dnia dzisiejszego zachował

1 Archiwum Główne Akt Dawnych (dalej: AGAD), Księgi miejskie białostockie, sygn. 1-3. 
się jedynie niewielki fragment akt (3 woluminy) dokumentujący działalności ówczesnych białostockich sądów - burmistrzowskiego oraz landwójtowskiego. Brak większości ksiąg miejskich oraz innych, starszych archiwaliów dotyczących miasta nadają szczególną wagę ocalałym wpisom, zwłaszcza, że zawierają one istotny materiały dotyczący przeszłości Białegostoku. Należy także zaznaczyć, że transakcje nieruchomościami są jednym z najlepiej udokumentowanych w księgach sądowych przejawem aktywności gospodarczej mieszczan.

Badania dotyczące obrotu nieruchomościami są prowadzone od wielu lat ${ }^{2}$, choć prac na ten temat jest wciąż niewiele. W dużym stopniu utrudnia to przeprowadzenie analizy porównawczej, tak ważnej w historii gospodarczej. Podejmując tę problematykę jesteśmy zmuszeni posiłkować się publikacjami dotyczącymi zagadnień pokrewnych (np. pracami z zakresu socjotopografii), czy też monografiami poszczególnych miast, które przy omawianiu szerszej problematyki w większym i mniejszym stopniu zajmują się również badaniami rynku obrotu nieruchomości. Należy zaznaczyć, że temat dotyczący nabywania posesji w Białymstoku został już wcześniej podjęty przez Alinę Sztachelską-Kokoczkę ${ }^{3}$. W swoim artykule przedstawiła ona przede wszystkim wpływ właściciela miasta na transakcje kupna-sprzedaży nieruchomości oraz nadania czynione przez Branickich. Opracowanie to jest niewątpliwie cenne, jednak pozostawia pewien niedosyt. Publikacja pomija ważną $\mathrm{w}$ tego typu badaniach kwantytatywną analizę zjawiska, stanowi raczej studium ciekawszych kontraktów.

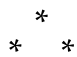

2 K. Bukowska, Orzecznictwo krakowskich sądów wyższych w sporach o nieruchomości miejskie (XVI-XVIII w.), Warszawa 1967; T. Zielińska, Szlacheccy właściciele nieruchomości w miastach XVIII w., Warszawa 1987; J. Rajman, O cenach nieruchomości w średniowiecznym Krakowie, „Teka Komisji Urbanistyki i Architektury” 1990, nr 24, s. 7-13; A. Mycio, Zadłużenie hipoteczne i obrót nieruchomości w Starym Mieście Toruniu w pierwszej połowie XVII w., Torun 2003; E. Barylewska-Szymańska, Gdański rynek nieruchomości w latach 1770-1776, [w:] Dom w mieście średniowiecznym i nowożytnym, red. B. Gediga, Wrocław 2004, s. 287-297; Obrót nieruchomościami na ziemiach polskich od średniowiecza do XX wieku, red. F. Kusiak, Poznań-Wrocław 2008; P. Łozowski, Rynek nieruchomości w Starej Warszawie w latach 1427-1453, „Klio. Czasopismo poświęcone dziejom Polski i powszechnym" 2016, t. 39, nr 4, s. 47-76.

3 A. Sztachelska-Kokoczka, Obrót nieruchomościami miejskimi na terenie Białegostoku w XVIII w., „Białostocczyzna” 1992, t. 28, nr 4, s. 6-9. Treść tego artykułu została powtórzona w monografii autorki z 2009 r., następnie zaś w zbiorowej publikacji dotyczącej historii Białegostoku. Zob. A. Sztachelska-Kokoczka, Białystok za pałacowa brama, Białystok 2009, s. 119-128; taż, Białystok w czasach Branickich (lata 1708-1795), [w:] Historia Białegostoku, red. A.Cz. Dobroński, Białystok 2012, s. 167-173. 
Osiemnastowieczny Białystok był jednym z większych miast podlaskich. W latach siedemdziesiątych tegoż stulecia ośrodek zamieszkiwało nieco ponad 2,5 tys. mieszkańców, z czego 41\% tanowili chrześcijanie, 35,5\% Żydzi, zaś 23,5\% żołnierze 4 . Zaznaczyć należy również, iż od lat trzydziestych XVIII stulecia Białystok był miastem garnizonowym (także w okresie pruskim i rosyjskim) oraz posiadał, jak na ówczesne czasy, silną załogę wojskową. Trudno jest jednoznacznie ustalić ilu żołnierzy tam przebywało - szacuje się, że pod koniec życia Branickiego stacjonowało ok. 450-500 wojskowych (łącznie z prywatną milicją) $)^{5}$. Natomiast w końcu XVIII stulecia ośrodek ten liczył w przybliżeniu 5 tys. osób (po odliczeniu wojska od ludności cywilnej miasto zamieszkiwało około 4 tys. osób), z czego ok. 36\% stanowili izraelici, a $20 \%$ żołnierze. Dla porównania dodajmy, że w tym samym czasie Tykocin zamieszkiwało 3 tys., Ciechanowiec i Siemiatycze nieco ponad 2,6, zaś Bielsk ok. 1,8 tys. mieszkańców ${ }^{6}$.

Pisząc o rynku nieruchomości należy również wspomnieć o budynkach znajdujących się na terenie miasta ${ }^{7}$. Niestety, nie znamy stanu zabudowy z początku XVIII stulecia. Wiemy natomiast, że w chwili przejęcia Białegostoku przez Jana Klemensa Branickiego przystąpiono do intensywnej rozbudowy miasta. Poza rezydencją oraz obiektami o charakterze publicznym wzniósł on również wiele domów mieszkalnych. W latach trzydziestych prowadził liczne prace budowalne przy ul. Kleindorf, zaś w pięćdziesiątych przy ulicach: Bojarskiej, Nowe Miasto, Zamkowej, a także przy austerii na rogu ul. Wasilkowskiej oraz najprawdopodobniej przy ul. Choroskiej. Hetman starał się również zachęcić mieszczan do inicjatyw budowlanych we własnym zakresie. Nie przyniosło to jednak oczekiwanych rezultatów, gdyż mieszkańcy miasta nie posiadali wystarczającej ilości środków finansowych oraz

4 K. Łopatecki, Ustrój XVIII-wiecznego miasta Białystok, „Miscellanea Historico-Iuridica” 2015, t. 14, z. 1, s. 351.

5 Tamże, s. 351.

6 Pruskie opisy miast polskich z końca XVIII wieku: departament białostocki, oprac. J. Wąsicki, Poznań 1964, s. 13, 51, 62, 78, 81; A.Cz. Dobroński, Białystok w latach 1796-1864, [w:] Historia Białegostoku, s. 216.

7 Należy także podkreślić, że miasto Białystok było otoczone od północy i zachodu (po prawej stronie rzeki Białej) przedmieściami, w skład których wchodziły ulice: Nowolipie, Przedmieścia Wasilkowskie, Bojarska, Zamkowa, Kleindorf, Nowe Miasto. Przedmieścia te nie tworzyły jednak odrębnej struktury miejskiej. Możemy jedynie przypuszczać, że były takie plany, o czym świadczy nadanie głównej ulicy prawobrzeżnych przedmieść nazwy Nowe Miasto. K. Lopatecki, dz. cyt., s. 358-359. 
materiałów budowlanych ${ }^{8}$. Pomimo tego wysiłki samego właściciela zaowocowały znacznym rozwojem Białegostoku. W momencie śmierci hetmana miasto liczyło w przybliżeniu 450 domów mieszkalnych, z czego ok. 170 należało do ludności żydowskiej. W niemalże 50 budynkach skarbowych mieszkali dworscy oficjaliści i rezydencji, a także służba. Dominowała zabudowa drewniana, parterowa, często wizualnie uboga. Istniało jedynie 46 w pełni murowanych obiektów (w tym 28 domów), zaś 43 posiadały otynkowaną lub ceglaną jedynie frontową ścianę. W mieście znajdowało się także wiele różnego rodzajów zabudowań gospodarczych ${ }^{9}$. Natomiast w końcu XVIII w. w Białystoku znajdowały się 462 domy (w tym 174 kryte dachówką, 288 gontami), a także 12 pustych placów oraz 30 stodół ${ }^{10}$. $Z$ kolei spis podatników z 1799 r. wymienia 442 budynki mieszkalne, zaś plan Beckera powstały w tym samym roku odnotowuje 459 domów ${ }^{11}$.

Nabywanie oraz zbywanie posesji było stałym elementem życia społeczno-gospodarczego nowożytnych miast. Dlatego ciągłość prowadzenia ksiąg miejskich było rzeczą ważną, zwłaszcza, że miały one charakter wieczysty. Z trzech zachowanych białostockich ksiąg miejskich oraz akt osobisto-rodzinnych i majątkowo-prawnych z zespołu Archiwum Roskiego udało się wyodrębnić 97 kontrakty kupna-sprzedaży różnych posesji (wykres 1). Na podstawie posiadanej bazy źródłowej, niestety, nie możemy w pełni ukazać dynamiki rynku nieruchomości, gdyż materiał źródłowy jest wielce niepełny. Najwięcej transakcji zanotowano w latach 1769-1775. Trzeba jednak zaznaczyć, że z lat siedemdziesiątych XVIII stulecia generalnie zachowała się największa liczba wpisów $\mathrm{w}$ księgach miejskich i najprawdopodobniej właśnie to jest przyczyną znacznej grupy informacji o transakcjach nieruchomościami. Tym samym uzyskane dane należy traktować jako przybliżone, niemniej jednak bardzo ważne dla dalszych rozważań nad historią miasta. Ich analiza pozwoli przede wszystkim na zorientowanie się w skali i charakterze badanego zjawiska.

8 A. Sztachelska, Białostocki ośrodek miejski w okresie działalności Jana Klemensa Branickiego. Zagadnienia prawno-ustrojowe, sądownictwo i zabudowa miasta, [w:] Studia i materiały do dziejów miasta Białegostoku, red. H. Majecki, t. 4, Białystok 1985, s. 77-78.

9 A. Sztachelska-Kokoczka, Białystok za pałacowa..., s. 105

10 Pruskie opisy miast.., s. 51.

11 A. Małek, Mieszkańcy Białegostoku pod zaborem pruskim, "Zeszyt Naukowy Muzeum Wojska” 1996, nr 10, s. 68-102; Spisy mieszkańców Białegostoku z lat 1799-1853, oprac. W. Wróbel, Białystok 2016, s. 20-43. 
Wykres 1. Liczba transakcji nieruchomościami w Białymstoku w XVIII w.

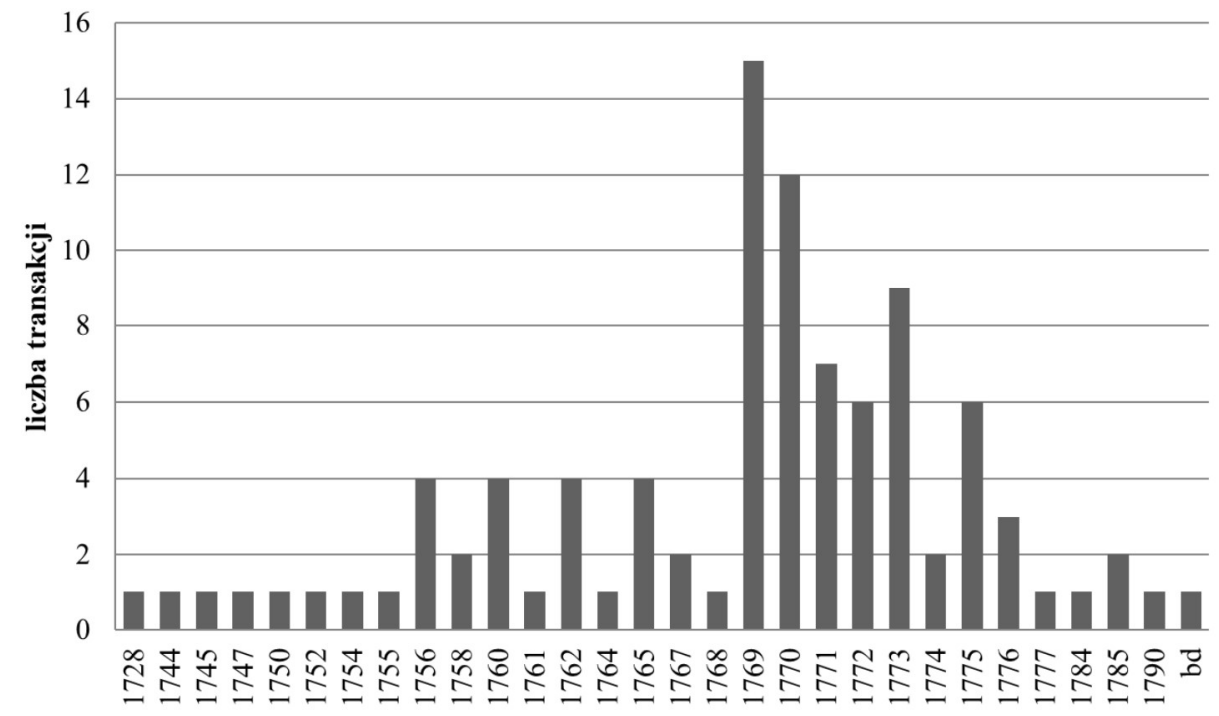

Źródło: AGAD, Księgi miejskie białostockie, sygn. 1-3, passim; AGAD, Archiwum Roskie, Akta osobisto-rodzinne i majątkowo-prawne, sygn. 628, passim.

Istotnym elementem $\mathrm{w}$ badaniach nad gospodarką jest określenie koncentracji danego zjawiska $\mathrm{w}$ ramach określonych grup zamożności. Dane przedstawione $\mathrm{w}$ tabeli 1 pokazują, że aż $64 \%$ wartości wszystkich kontraktów kupna-sprzedaży koncentrowała się w ręku małej grupy osób (6,2\% spraw). Duży udział w rynku posiadały niewielkie transakcje (do 100 złp - 40,2\% wpisów), lecz ich wartość stanowiła margines obrotów (4,4\%). Licznie występowały również posesje (40,2\% spraw), których cena wahała się w przedziale 101-500 złp, miały one już większy udział w wartości całego rynku (22,2\%). Należy zaznaczyć, że największym zainteresowaniem cieszyły się transakcje do 500 zlp - łącznie stanowiły one nieco ponad 80\% liczby wszystkich kontraktów, a ich wartość nieznacznie przekraczała jedną czwartą całości obrotów.

Nabycia posesji w osiemnastowiecznym Białymstoku, podobnie jak w innych ośrodkach urbanistycznych, należało dokonać przed sądem miejskich. Alienacja taka odbywała się $\mathrm{w}$ formie pisemnej. Do urzędu stawiały się obie zainteresowane strony, zarówno kupujący i sprzedający nieruchomość, nierzadko oboje małżonków. W dokumencie podawano ich personalia, następnie starano się dokładnie opisać przedmiot transakcji (przykładowo „domo- 
Tabela 1. Struktura wartości obrotów nieruchomościami w Białymstoku w latach 1728-1790

\begin{tabular}{|l|c|c|c|c|c|c|}
\hline \multirow{2}{*}{ Wyszczególnienie } & \multicolumn{7}{|c|}{ Wartość [złp] $^{*}$} \\
\cline { 2 - 7 } & do 100 & $101-500$ & $501-1000$ & $\begin{array}{c}\text { powyżej } \\
1000\end{array}$ & $\begin{array}{c}\text { wartość } \\
\text { nieznana }\end{array}$ & ogółem \\
\hline Liczba transakcji & 39 & 39 & 6 & 6 & 7 & 97 \\
\hline $\begin{array}{l}\text { Wartość transakcji } \\
\text { [złp] }\end{array}$ & 1875 & 9330 & 3950 & 26800 & - & 41955 \\
\hline$\%$ liczby & 40,2 & 40,2 & 6,2 & 6,2 & 7,2 & 100 \\
\hline$\%$ wartości & 4,4 & 22,2 & 9,4 & 64 & - & 100 \\
\hline
\end{tabular}

* Wartość transakcji przeliczona na złote polskie na podstawie: Z. Żabiński, Systemy pieniężne na ziemiach polskich, Wrocław 1981, s. 132 (tabela 78), 138 (tabela 81).

Źródło: AGAD, Księgi miejskie białostockie, sygn. 1-3, passim; AGAD, Archiwum Roskie, Akta osobisto-rodzinne i majątkowo-prawne, sygn. 628, passim.

stwo z placem i ze wszystkim obrządkiem"12) oraz podawano jego cenę. Położenie posesji określano wymieniając nazwę ulicy, sąsiadów z którymi graniczyła bądź też inne istotne elementy topograficzne lub architektoniczne (np. rzeczka, pola bojarskie, parkan miejski, cerkiew unicka). Zazwyczaj pojawiała się również formuła mówiąca, że nieruchomość tą zbyto „wiecznoto z kamieniami, z wodami". Czasem podawano również dokładne wymiary placu. Tego rodzaju dane szczegółowo zanotowano m.in. przy transakcji zawartej między Magdaleną Zimnochowską a małżeństwem Czerniawskich - zakupiony plac miał „długości [...] od uliczki nad rzeczką do księżego ogrodu łokci 147, szerokości od rzeczki łokci 40, a od ogrodu księży farnych łokci 32"13. Pod takim aktem kupna-sprzedaży nieruchomości podpisywali się: zbywca, nabywca, członkowie magistratu oraz świadkowie, jeżeli tacy byli obecni przy transakcji. Zdarzało się również, że „dla lepszej wiary i wagi" dokument zaopatrywany był pieczęcią miejską.

Problemem nurtującym każdego badacza są przyczyny danego zjawiska - w tym przypadku powody wystawienia na sprzedaż danej nieruchomości. Niestety kwestia ta nie jest poruszana w źródłach. Możemy jednak przypuszczać, że często przyczyną transakcji mogło być pogorszenie sytuacji majątkowej dotychczasowego właściciela, który nie był w stanie utrzymać

12 AGAD, Księgi miejskie białostockie, sygn. 1, s. 60.

13 AGAD, Księgi miejskie białostockie, sygn. 3, s. 106. 
danej posesji. Kolejnym powodem była potrzeba uregulowania spraw majątkowych, głównie w przypadku dziedziczenia jednego budynku czy też działki przez kilka osób. Nieruchomości sprzedawano także, gdy ich posiadanie przestawało być opłacalne - nie przynosiły one pożądanych dochodów. Jeszcze inną przyczyną mogła być po prostu wola zmiany parceli, kiedy to obecny posiadacz sprzedawał starą oraz nabywał nową, lepszą posesję. Czasem dążono jednak do zamiany danego lokum na gorsze, ale jednocześnie tańsze w utrzymaniu. Nieruchomości kupowano zaś z powodu chęci posiadania lokalu mieszkalnego lub miejsca do pracy.

Wykres 2. Udział handlu wybranymi rodzajami nieruchomości w Białymstoku w latach 1728-1790

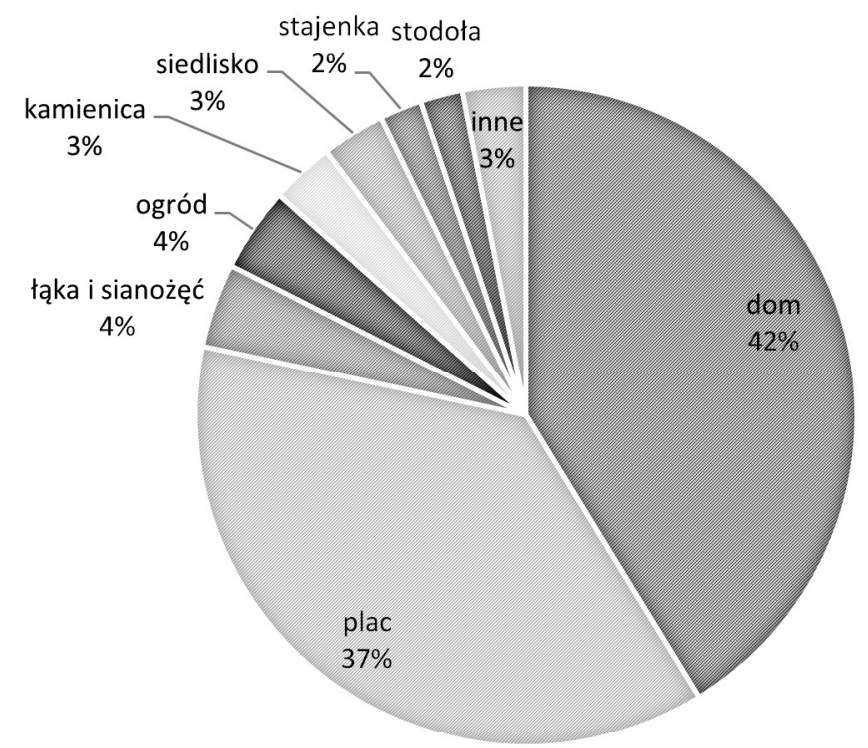

Źródło: AGAD, Księgi miejskie białostockie, sygn. 1-3, passim; AGAD, Archiwum Roskie, Akta osobisto-rodzinne i majątkowo-prawne, sygn. 628, passim.

Co zaś stanowiło przedmiot transakcji kupna-sprzedaży nieruchomości? Mógł to być lokal mieszkalny (w źródle pojawiają się takie określenia jak: chałupa, dom, domostwo, budynek, kamienica) oraz inne zabudowania (browar, stodoła, stajenka), bądź grunty (zob. wykres 2). W księgach miejskich odnotowano 40 kontraktów (42\% wszystkich spraw) dotyczących kupna-sprzedaży drewnianych domów oraz 3 wpisy tyczące się kamienic (3\%). Często przy takich transakcjach pojawiał się dopisek, że dany budynek zbyto wraz z placem, ogrodem, obiektami gospodarczymi bądź całym obrządkiem. Należy zaznaczyć, że większa część mieszkańców Białegostoku posiadała przy 
swoich domach różnego rodzaju ogrody warzywne, sady oraz zabudowania gospodarcze. Z kolei aż 36 wpisów (37\%) odnosiło się do kupna-sprzedaży placów, z czego przy 8 transakcjach zaznaczono, iż mają one zostać przeznaczone pod wybudowanie browaru. Margines obrotów - jedynie 8\% wpisów stanowił zaś handel ziemią rolną (ogród, łąka, sianożęć). Należy zaznaczyć, że część mieszkańców zajmowała się rolnictwem, jednakże specyfika Białegostoku doprowadziła to tego, że pastwisk na terenie badanego ośrodka urbanistycznego było bardzo mało ${ }^{14}$. W końcu XVIII w. w granicach miasta pozostawało jedynie 6 hektarów pól i łąk ${ }^{15}$. Ponadto, do ksiąg sądowych wciągnięto transakcje odnoszące się do kupna-sprzedaży 2 stajenek, 2 stodół (gumna), czy też browaru.

Tabela 2. Struktura rynku obrotu nieruchomości w zależności od rodzaju posesji w Białymstoku w latach 1728-1790

\begin{tabular}{|c|c|c|c|c|c|c|}
\hline \multirow{2}{*}{ Rodzaj nieruchomości } & \multirow{2}{*}{ Liczba } & \multirow{2}{*}{$\%$ liczby } & \multicolumn{2}{|c|}{ Cena [złp] } & \multirow{2}{*}{$\begin{array}{c}\text { Całkowita } \\
\text { wartość } \\
\text { transakcji } \\
\text { [złp] }\end{array}$} & \multirow{2}{*}{$\%$ wartośc } \\
\hline & & & Średnia & Mediana & & \\
\hline Dom & 40 & 42 & 509 & 275 & 20374 & 48,56 \\
\hline Kamienica & 3 & 3 & 5800 & 6000 & 17400 & 41,5 \\
\hline Plac & 36 & 37 & 97 & 64 & 3110 & 7,4 \\
\hline Ogród & 4 & 4 & 31,5 & 27 & 126 & 0,3 \\
\hline Łąka i sianożęć & 4 & 4 & - & - & 18 & 0,04 \\
\hline Siedlisko & 3 & 3 & - & - & 380 & 0,9 \\
\hline Stajenka & 2 & 2 & 19,5 & 19,5 & 39 & 0,1 \\
\hline Stodoła & 2 & 2 & 43 & 43 & 86 & 0,2 \\
\hline Inne & 3 & 3 & 141 & 160 & 422 & 1 \\
\hline Razem & 97 & 100 & 466 & 126 & 41955 & 100 \\
\hline
\end{tabular}

Źródło: AGAD, Księgi miejskie białostockie, sygn. 1-3, passim; AGAD, Archiwum Roskie, Akta osobisto-rodzinne i majątkowo-prawne, sygn. 628, passim.

Kolejnym zagadnieniem wartym rozważenia jest wartość posesji. Określano ją na podstawie dobrowolnej umowy między stronami transakcji, bądź też po uprzednim otaksowaniu nieruchomości. Czynność taką przeprowadzał cały magistrat, wraz ze sprowadzonym specjalistą $\mathrm{w}$ danej dziedzinie

\footnotetext{
14 K. Lopatecki, W. Walczak, The history of Branicki Palace until 1809. The influence of "Versailles of Podlasie" on the development of Bialystok, Białystok 2015, s. 73.

15 A.Cz. Dobroński, dz. cyt., s. 216-217.
} 
(np. drewniany dom pomagał wycenić cieśla), jeżeli zaś miała ona dotyczyć parceli żydowskiej, obecny był przy tym także przedstawiciel kahału ${ }^{16}$. W większości zapisów (93\%) dotyczących handlu nieruchomościami wymieniono dokładną wartość transakcji. Umożliwia to opracowanie zestawienia zawierającego szacunkową cenę różnego rodzaju posesji (zob. tabela 2). Ceny nieruchomości w Białymstoku były bardzo zróżnicowane i wyraźnie widać, wynikały z rodzaju posesji. Najtańsze były grunty takie, jak ogrody, łąki, czy sianożęcia oraz zabudowania gospodarcze (stajenka, stodoła i inne). Droższe były place - ich średnia cena wynosiła 97 złp. Wydaje się, że koszt zakupu pustej parceli związany był także z jej lokalizacją i przeznaczeniem. Przykładowo cena placu zakupionego pod budowę browaru, znajdującego się przy parkanie Zwierzyńca, kształtowała się w granicach od 50 do 110 złp, zaś puste działki mieszczące się przy odchodzącej od Rynku ul. Wasilkowskiej kosztowały od 58 do nawet 380 złp. Należy zaznaczyć, że ich nabywcą był głównie właściciel miasta - Jan Klemens Branicki, możemy wysnuć przypuszczenie, że chciał one je przeznaczyć pod budowę budynków skarbowych. Należy także zauważyć, że handel różnego rodzaju gruntami w mieście osiągał jedynie $7,74 \%$ wartości wszystkich umów, mimo że stanowił aż $45 \%$ liczby wszystkich transakcji.

Ceny obiektów mieszkalnych kształtowały się najprawdopodobniej w związku z rodzajem zabudowy, choć w źródle rzadko pojawiają się dokładne opisy sprzedawanych nieruchomości, a szczegółowe informacje na temat zbywanych posesji pojawiają się tylko w nielicznych wpisach. Przykładowo, w styczniu 1772 r. Jan i Ludwika Bemowie nabyli za sumę 300 złp od Stefan i Zofii Wasilewskich domostwo z jednym kominem, o dwóch izbach i sieni ${ }^{17}$. Natomiast Józef i Marianna Złotoszewscy w kwietniu 1772 r. kupili drewniany dom kryty dachówką za kwotę 500 złp ${ }^{18}$. Należy również zaznaczyć, że najtańsze budynki w księgach miejskich określane są jako chałupa (9 transakcji). Średni koszt takiego lokum kształtował się na poziomie $155 \mathrm{złp}$, mediana - 161 złp (cena wahała się zaś od 45 do 240 złp). Droższe posesje określano mianem domostwa, domu, budynku (średnia cena - 612 złp; mediana - 315 złp). Z kolei ogólny średni koszt zakupu lokum mieszkaniowego w Białystoku wynosił 509 złp, mediana zaś 275 złp. Umowy kupna-sprzedaży domów osiągały największą wartość $(48,56 \%)$ ze wszystkich transakcji.

\footnotetext{
16 A. Sztachelska-Kokoczka, Białystok za pałacową..., s. 124-125; taż, Obrót nieruchomościami..., s. 8

17 AGAD, Księgi miejskie białostockie, sygn. 3, s. 22.

18 AGAD, Księgi miejskie białostockie, sygn. 2, s. 57-58.
} 
Do najdroższych posesji w mieście należały murowane kamienice - osiągały one $41,5 \%$ wartości wszystkich umów, mimo że stanowiły one jedynie $3 \%$ liczby wszystkich kontraktów. Jedna $\mathrm{z}$ transakcji kupna-sprzedaży takiej posesji miała miejsce w styczniu 1771 r., kiedy to Katarzyna z Majewskich, wdowa po Marcinie Szorcu, sprzedała położoną przy ul. Suraskiej murowaną narożną kamienicę o dwóch piętrach, wraz ze stajnią oraz spichlerzem, a także mieszczący się przy ul. Święto Rochskiej za Bramą Choroską drewniany dworek (opisane nieruchomości w 1766 r. nadał jej Jan Klemens Branicki ${ }^{19}$ ). Posesje te nabył, za niebagatelną sumę 9000 złp, poczmajster białostocki Karol Topolski ${ }^{20}$. Co ciekawe, był on już posiadaczem jednej kamienicy w Grodnie ${ }^{21}$. Kontrakt ten był największą odnotowaną w białostockich księgach miejskich transakcją ${ }^{22}$. Z kolei w październiku $1785 \mathrm{r}$. sukcesorzy po landwójcie Antonim Wroczyńskim zbyli odziedziczoną austerię małżeństwu Langierów, za niebagatelną sumę 6000 złp ${ }^{23}$. Zaś we wrześniu tegoż roku Marianna z Kamińskich Ryciuszowa w imieniu swego małoletniego syna Stanisława sprzedała kamienicę mieszczącą się przy ul. Wasilkowskiej, Adamowi Henrykowi Mengierowi - białostockiemu lekarzowi, za sumę 2400 złp. $\mathrm{Z}$ treści dokumentu dowiadujemy się, że dotychczasowi właściciele posesji otrzymali pozwolenie dworu na jej sprzedaż ${ }^{24}$.

Dla porównania dodajmy, że w osiemnastowiecznym Staszowie cena placu w centrum miasta kształtowała się na poziomie $60 \mathrm{złp}$, przy ulicach wychodzących z Rynku - 30 złp, zaś w dalszych częściach miasteczka ok. 20 złp polskich. Koszt domostwa wynosił 140, 240 lub 270 złp, z kolei chałupkę można było nabyć za 10, 15 i 20 złp, kamienicę zaś za 5000 złp ${ }^{25}$. Natomiast w Tomaszowie Lubelskim wycena większości domów w mieście kształtowała się na poziomie od 200 do 300 złp, zaś najdroższy drewniany dom rynkowy kosztował 1000 złp ${ }^{26}$.

19 AGAD, Archiwum Roskie, Akta osobisto-rodzinne i majątkowo-prawne, sygn. 628, s. 31.

20 AGAD, Księgi miejskie białostockie, sygn. 2, s. 44-45; AGAD, Archiwum Roskie, Akta osobisto-rodzinne i majątkowo-prawne, sygn. 628, s. 32.

21 AGAD, Księgi miejskie białostockie, sygn. 3, s. 127

22 Najprawdopodobniej najdroższą nieruchomością na terenie miast, oprócz Pałacu Branickich, była tzw. Bażantarnia (założenie ogrodowo-dworskie). Miała ona trafić do spadkobierców Jana Klemensa Branickiego. Izabela Branicka zapłaciła za jej odstąpienie dotychczasowym lokatorom 13020 złp. M. Kupczewska, K. Łopatecki, Testament Izabeli z Poniatowskich Branickiej (3 XI 1805), „Kwartalnik Historii Kultury Materialnej” 2016, t. 64, nr 1, s. 111.

23 AGAD, Księgi miejskie białostockie, sygn. 2, s. 85-87.

24 AGAD, Księgi miejskie białostockie, sygn. 3, s. 174-175.

25 A. Makowska, Prywatne miasto Staszów i dobra staszowskie, Warszawa 1981, s. 98-99, 104.

26 E. Hanejko Miasto w okresie od wielkiego sporu o Ordynację do I rozbioru Polski, [w:] Tomaszów Lubelski: monografia miasta, red. R. Szczygieł, Lublin-Tomaszów Lubelski 2011, s. 136. 
Warto także zaznaczyć, że w 1802 r. władze pruskie spisały dokładny inwentarz oceniający wartość pałacu, oficyn, ogrodu oraz budynków dworskich położonych na terenie Białegostoku ${ }^{27}$. Niewątpliwie źródło te zawiera istotne informacje dotyczące historii badanego ośrodka miejskiego, jednakże podaje jedynie wycenę budynków będących własnością spadkobierców Jana Klemensa Branickiego, nie odnotowuje zaś wiadomości na temat nieruchomości należących do białostockich mieszczan.

Tabela 3. Ceny wybranych rodzajów nieruchomości (dom i plac) w zależności od położenia w Białymstoku w latach 1728-1790

\begin{tabular}{|c|l|c|l|}
\hline $\begin{array}{c}\text { Rodzaj } \\
\text { nieruchomości }\end{array}$ & \multicolumn{1}{|c|}{ Lokalizacja } & $\begin{array}{c}\text { Liczba } \\
\text { transakcji }\end{array}$ & \multicolumn{1}{|c|}{ Cena [złp] } \\
\hline \multirow{5}{*}{ Dom } & Rynek & 2 & 5000,3000 \\
& ul. Choroska & 1 & 1400 \\
& ul. Nowe Miasto & 3 & $750,500,400$ \\
& ul. Wasilkowska & 10 & $650,600,500,470,300,300$, \\
& za łaźnią żydowską & 2 & 550,105 \\
& ul. Gumienna & 3 & $418,345,300$ \\
& Nad rzeką & 1 & 300 \\
& ul. Suraska & 4 & $240,225,114,90$ \\
& ul. Tylna & 1 & 100 \\
& ul. Kleindorf & 1 & 100 \\
& za bramą wasilkowską & 1 & 60 \\
& przy parkanie Zwierzyńca & 1 & 45 \\
\hline \multirow{5}{*}{ Plac } & ul. Wasilkowska & 8 & $380,220,200,200,200,127$, \\
& ul. Zielona & 3 & $180,100,28$ \\
& ul. Gumienna & 4 & $170,60,30,19$ \\
& przy parkanie Zwierzyńca & 8 & $110,104,100,80,60,60,55$, \\
& nad rzeką & 2 & 110,44 \\
& za bramą suraską & 68,32 \\
& ul. Suraska & 32 \\
\hline
\end{tabular}

Źródło: AGAD, Księgi miejskie białostockie, sygn. 1-3, passim; AGAD, Archiwum Roskie, Akta osobisto-rodzinne i majątkowo-prawne, sygn. 628 , passim.

27 Zob. Pałac Branickich w Białymstoku, t. 2: Lata 1802-1809, oprac. K. Łopatecki, W. Walczak, Białystok 2015, s. 232-279; K. Łopatecki, Sprzedaż dóbr białostockich przez spadkobierców Jana Klemensa Branickiego, „Studia Podlaskie” 2015, nr 23, s. 75-99. 
W przypadku $82 \%$ transakcji wymieniono położenie nieruchomości przez podanie nazwy ulicy, sąsiadów, bądź elementów topograficznych i architektonicznych (np. rzeczka, parkan, łaźnia). W tabeli 3 przedstawiono ceny lokali mieszkalnych i placów w zależności od lokalizacji, uwzględniono w niej jedynie domy i place, ze względu na zbyt małą liczbę innych nieruchomości. Najwyższe ceny osiągały nieruchomości usytuowane przy Rynku i ulicach zlokalizowanych w niewielkiej odległości od niego (ul. Wasilkowska, Choroska). Wysoko wyceniono również domy zlokalizowane przy ul. Nowe Miasto. Była to główna ulica prawobrzeżnych przedmieść Białegostoku ${ }^{28}$, którą zamieszkiwali oficjaliści i służba dworska ${ }^{29}$. Niższe ceny nieruchomości odnotowano w dzielnicy żydowskiej (ul. Suraska, Tylna). Podobną zależność możemy zaobserwować w przypadku placów - ich cena uzależniona była przede wszystkim od wielkości oraz lokalizacji przestrzennej. Grunty położone przy ul. Warszawskiej są o wiele droższe od placów zlokalizowanych w innych częściach miasta.

Wykres 3. Terminy zawarcia transakcji kupna-sprzedaży nieruchomości w Białymstoku w latach $1728-1790$

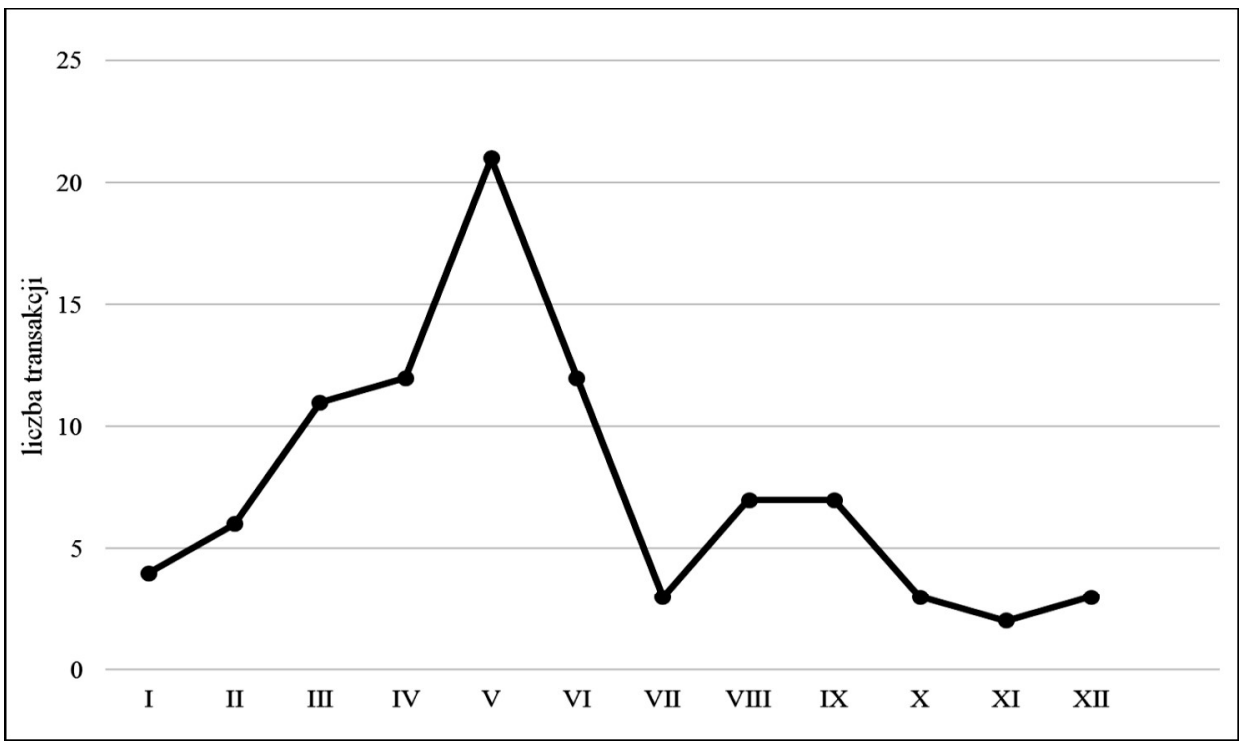

Źródło: AGAD, Księgi miejskie białostockie, sygn. 1-3, passim; AGAD, Archiwum Roskie, Akta osobisto-rodzinne i majątkowo-prawne, sygn. 628, passim.

28 K. Łopatecki, Ustrój..., s. 355, 358-159.

29 A. Oleksicki, Socjotopografia Białegostoku w XVIII w. w świetle inwentarza miasta z 1771/72 i planu Beckera z 1799 r., [w:] Studia i materiały..., s. 55. 
Warto również zastanowić się nad terminem zawarcia umowy kupna-sprzedaży nieruchomości. Szczyt zapisów przypada przede wszystkim na okres wiosenny - $\mathrm{w}$ terminie od marca do czerwca do ksiąg wpisano aż $61,5 \%$ wszystkich transakcji. Należy jednak zaznaczyć, że tak duży skok liczby umów w maju (21 wpisów) związany był po części z wykupieniem przez Branickiego posesji znajdujących się przy ul. Wasilkowskiej (7 transakcji w dniach 10-11 maja 1770 r.). Jednym z elementów determinującym zawieranie kontraktów w tym okresie mogły być m.in. warunki pogodowe, które sprzyjały wszelkiego rodzaju pracom remontowym i samej przeprowadzce.

Tabela 4. Aktywność uczestników rynku obrotu nieruchomościami w Białymstoku w latach $1728-1790$

\begin{tabular}{|c|c|c|c|c|c|c|}
\hline \multirow{2}{*}{\multicolumn{2}{|c|}{ Wyszczególnienie }} & \multicolumn{5}{|c|}{ Liczba transakcji kupna nieruchomości } \\
\hline & & 0 & 1 & 2 & 3 & 4 i więcej \\
\hline \multirow{4}{*}{ 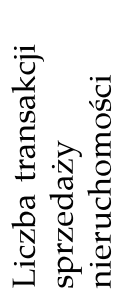 } & 0 & - & 63 & - & 1 & - \\
\hline & 1 & 68 & 9 & 2 & 1 & 1 \\
\hline & 2 & 7 & 1 & - & - & - \\
\hline & 3 & 1 & - & - & - & - \\
\hline
\end{tabular}

Źródło: AGAD, Księgi miejskie białostockie, sygn. 1-3, passim; AGAD, Archiwum Roskie, Akta osobisto-rodzinne i majątkowo-prawne, sygn. 628, passim.

Białostocki rynek obrotu nieruchomościami charakteryzował się jednokrotną obecnością osób w nim uczestniczących (zob. tabela 4). Przeciętny mieszkaniec miasta tylko sprzedawał (76 osób) lub kupował (64 osoby) nieruchomość, występując po jednej stronie rynku. Należy pamiętać, że nabycie bądź zbycie posesji nie jest czynnością dokonywaną zbyt często, zaś osoby które uczestniczył $\mathrm{w}$ handlu nieruchomościami zapewne robiły to raz $\mathrm{w}$ życiu (63 osoby tylko raz kupiły nieruchomość, zaś 68 osób raz sprzedało posesję).

$\mathrm{Z}$ zachowanych akt kupna-sprzedaży nieruchomości wynika, że posesje zbywały głównie osoby o polsko brzmiących nazwiskach, stanowiły one aż $86 \%$ sprzedających. Wiele z nich nabywało również nieruchomości (47\%). Parcele kupowali również izraelici - stanowiący 42\% nabywców (rzadziej zaś zbywali posesje - $\mathrm{w}$ analizowanym materiale osoby pochodzenia żydowskiego stanowiły jedynie $6 \%$ sprzedający). Pozyskane przez nich posesje mie- 
ściły się w Rynku oraz przy ulicach: Suraskiej, Choroskiej, Tylnej, Wasilkowskiej. Do jednej z takich transakcji doszło 25 marca 1756 r., gdy Jan Syczewicz wraz z żoną Małgorzatą sprzedali domostwo przy ul. Suraskiej Zelmanowi Hilewiczowi za 114 złp $^{30}$. W tej części miasta nieruchomość zakupili także cymbalista Ickow Boruchowicz ${ }^{31}$, Dawid Chackiewicz ${ }^{32}$ oraz Wigdorow Aronowicz ${ }^{33}$. Z kolei przy ul. Tylnej w 1762 r. chałupę z placem za 100 złp nabył Rodzim Chaimowicz ${ }^{34}$. Wyraźnie więc widać, że starozakonni skupowali nieruchomości znajdujące się $\mathrm{w}$ centrum miasta, a przede wszystkim w ciągle powiększającej się dzielnicy żydowskiej ${ }^{35}$. Również w innych ośrodkach urbanistycznych (m.in. w Siemiatyczach ${ }^{36}$, czy pobliskim Wasilkowie ${ }^{37}$ ) izraelici osiedlali się głównie w okolicach rynku i w śródmieściu, gdyż właśnie tam istniały skupiska ludności trudniącej się handlem oraz rzemiosłem. Nie wydaje się jednak, żeby posesje sprzedawane ludności żydowskiej były droższe, niż te nabywane przez chrześcijan, mimo że izraelici uważani byli za zamożniejszych mieszkańców miasta.

Parcele $\mathrm{w}$ mieście kupowały nie tylko osoby indywidualne - przykładowo w lipcu 1752 r. Adam Ochremowicz oraz Marcin Adamczuk sprzedali dość duży obszar własnej ziemi, liczący 35 prętów ${ }^{38}$, kahałowi białostockiemu. Grunt ten miał być przeznaczony na kirkut ${ }^{39}$. Niestety, dokument nie podaje jego lokalizacji, najprawdopodobniej jednak cmentarz ten znajdował się na przedmieściu suraskim ${ }^{40}$. Posesje od mieszczan białostockich nabywał również skarb dworski ${ }^{41}$. W handlu nieruchomościami brały udział także kobiety - w 16 przypadkach to one zbywały posesję, w jednej tylko transakcji niewiasta była nabywcą. W 1775 r. Stanisławowa Pręczyńska kupiła od

30 AGAD, Księgi miejskie białostockie, sygn. 3, s. 41

31 AGAD, Księgi miejskie białostockie, sygn. 1, s. 85.

32 Tamże, s. 105

33 Tamże, s. 43.

34 Tamże, s. 77.

35 Dzielnica żydowska w osiemnastowiecznym Białymstoku znajdowała się w Rynku i południowej części Starego Miasta. Zob. A. Oleksicki, dz. cyt., s. 55.

36 Tenże, Zabytki architektury $w$ Siemiatyczach a przemiany $w$ przestrzennym rozplanowaniu miasta w XVIII w., [w:] Studia i materiały do dziejów miasta Siemiatycze, red. H. Majecki, Warszawa 1989 , s. 48

37 P. Czyżewski, Gospodarka Wasilkowa - miasteczka pogranicza Korony i Litwy - w XVI-XVIII wieku, [w:] Małe miasta. Gospodarka, red. M. Zemło, Lublin-Supraśl 2007, s. 80

381 pręt równał się 1,5 ha.

39 AGAD, Księgi miejskie białostockie, sygn. 1, s. 22.

40 T. Wiśniewski, Cmentarze żydowskie w Białymstoku, "Studia Podlaskie” 1989, nr 2, s. 383-385.

41 AGAD, Księgi miejskie białostockie, sygn. 2, s. 27-29, 31-34, 36-37. 
Wojciecha i Katarzyny Dziedzichowiczów ogród położony przy ul. Kleindorf za sumę 24 złp $^{42}$. Z kolei w 1773 r. Marianna Pasińska oraz Magdalena Zimnochowska, pod nieobecność swoich mężów, sprzedały połowę placu nad rzeczką Józefowi Ormoanowskiemu ${ }^{43}$. Zdarzało się, że nieruchomość zbywały wdowy (8 spraw), które najprawdopodobniej nie były w stanie samodzielnie utrzymać posesji. Tak stało się we wrześniu 1765 r., kiedy to Szymon Dombrowski kupił od Agnieszki Bartłomiejowej wdowy chałupę za 219 złp 44 . Zaś w czerwcu 1769 r. Konstancja Hołubowska sprzedała plac mieszczący się przy ul. Wasilkowskiej Markowi Szlomowiczowi ${ }^{45}$.

Nieruchomość można było nabyć za gotówkę, wpłacając całość kwoty przy zawieraniu kontraktu, bądź spłacać ją ratami. W analizowanych źródłach znaleziono jedynie szczątkowy materiał dotyczący spłaty nieruchomości ratami. Przykładem takiej umowy kupna-sprzedaży, jest kontrakt zawarty w styczniu 1771 r., kiedy to Jan Bemm z żoną Ludwiką kupili dom nad rzeczką od Stefana i Zofii Wasilewskich za 300 złp. Z tej sumy 100 złp zapłacono od razu, resztę zaś wypłacono 29 września następnego roku ${ }^{46}$. Natomiast przy sprzedaży kamienicy należącej niegdyś do Antoniego Wroczyńskiego, Jan i Marianna Landiger przy transakcji wypłacili gotówką połowę kwoty (3000 złp), a pozostałą sumę mieli spłacić w przeciągu trzech lat ratami, każda po tysiąc złotych. Kredyt ten był również oprocentowany - prowizja wynosiła 10\% ${ }^{47}$. Z kolei Teresa Brzozowska zarówno w sierpniu, jak i grudniu 1785 r. odbierała należne jej kwoty z tytułu sprzedaży domu Janowi Zachariaszowi ${ }^{48}$.

Transakcje kupna-sprzedaży nieruchomości mogły być dodatkowo obwarowane różnymi kryteriami, np. czasowym bezpłatnym użytkowaniem danej posesji przez dawnego właściciela. Taka sytuacja miała miejsce przy kontrakcie zawartym w 1774 r., kiedy to Stanisławowa Pręczyńska sprzedając stodołę Henrychtowi Kimanowi zastrzegła sobie prawo trzymania w niej zboża do przyszłego lata ${ }^{49}$. Z kolei w marcu 1775 r. Szloma Kuriański, kupując dom od Piotra i Magdaleny Burzyńskich, zadeklarował przyznanie im dożywocia. Ponadto, Burzyńscy mieli również obowiązek świadczenia

42 AGAD, Księgi miejskie białostockie, sygn. 3, s. 94

43 Tamże, s. 23.

44 AGAD, Księgi miejskie białostockie, sygn. 1, s. 73.

45 AGAD, Księgi miejskie białostockie, sygn. 2, s. 51-52.

46 Tamże, s. 66.

47 Tamże, s. 85-87.

48 AGAD, Księgi miejskie białostockie, sygn. 3, s. 171, 180.

49 Tamże, s. 84-85. 
na rzecz nabywcy usług bednarskich w wysokości 3 złp rocznie ${ }^{50}$. Podobne zapisy dożywocia miały również miejsce przy kontraktach zawartych przez wdowę Agnieszkę Barłłomiejową Szaciłowską ${ }^{51}$, Karola Danielewicza ${ }^{52}$ oraz Stefana i Zofię Wasilewskich ${ }^{53}$.

Pewną odmianą operacji kupna-sprzedaży były transakcje wymiany, które praktycznie rządziły się tymi samymi prawami, co handel nieruchomościami. Kontraktów takich było jednak niewiele. Polegały one na zamianie nieruchomości między stronami. Przypuszczalnie były one również bezgotówkowe, ewentualnie $\mathrm{z}$ użyciem pieniądza, który wyrównywał różnicę wynikającą z odmiennej wartości posesji. Znane z ksiąg miejskich transakcje wymiany odbywały się między mieszkańcami Białegostoku a właścicielem miasta. Przykładem takiej operacji jest kontrakt z 2 marca 1770 r., w którym bojar Wojciech Jackowski Puchalik zrzekł się swojej posesji położonej przy ul. Bojarskiej na rzecz Branickiego, w zamian zaś otrzymał siedlisko i ćwierć gruntu. Nieruchomość ta należała wcześniej do pracowitego Jędrzeja Jarosza z Krywlan, a wykupiona została przez skarb dworski ${ }^{54}$. Podobnie stało się z należącym do Jana Majewskiego budynkiem przy ul. Wasilkowskiej, hetman wymienił tą posesję na inną mieszczącą się za bramą wasilkowską ${ }^{55}$.

Po wpisaniu aktu kupna-sprzedaży nieruchomości do ksiąg miejskich, dodatkowo należało jeszcze ogłosić fakt zawarcia takiego kontraktu mieszkańcom miasta. Służyło temu wwiązanie (intromissio), czyli wprowadzenie $\mathrm{w}$ posiadanie. Intromisja odbywała się na terenie posesji, w obecności całego magistratu, co dodatkowo podkreślało znaczenie tej czynności. Trzykrotnie obwieszczano wówczas wszystkim zgromadzonym o dokonanej transakcji, następnie opisywano, czasem wręcz obchodzono zakupioną nieruchomość56. Praktyka ogłaszania intromisji na sprzedanej parceli utrzymała się do końca XVIII stulecia w większości miast prywatnych ${ }^{57}$.

\footnotetext{
50 Tamże, s. 95.

51 Tamże, s. 7

52 AGAD, Księgi miejskie białostockie, sygn. 1, s. 73.

53 AGAD, Księgi miejskie białostockie, sygn. 2, s. 66.

54 Tamże, s. 27-29.

55 Tamże, s. 62.

56 Tamże, s. 35, 36, 61-62; A. Sztachelska-Kokoczka, Białystok za pałacową..., s. 127; taż, Obrót nieruchomościami..., s. 9.

57 T. Opas, Własność w miastach i jurydykach prywatnych w dawnej Polsce: studium historyczno-prawne, Lublin 1990, s. 186.
} 
Jak wynika z przytoczonych wyżej przykładów, mieszkańcy Białegostoku mieli silnie rozwinięte poczucie własności, którą mogli użytkować, zastawiać, sprzedawać oraz dziedziczyć. Jednakże przy alienacji nadal wymagana było zgoda właściciela ośrodka urbanistycznego (działo się tak we wszystkich miastach prywatnych) ${ }^{58}$. Wszystkie akty kupna-sprzedaży zamieszczane $\mathrm{w}$ białostockich księgach miejskich doszły do skutku, tym samym możemy przypuszczać, że zawarcie danych transakcji działo się za przyzwoleniem dworu. Natomiast nie posiadamy informacji o kontraktach, na które Braniccy nie wyrazili zgody, dlatego też zjawisko to jest trudne do uchwycenia. Swoistym przykładem takiego zezwolenia na zawarcie transakcji jest przywilej Izabeli Branickiej wydany dla Daniela Lenkiewicza poczmajstra i jego żony Katarzyny z Topolskich na domostwo mieszczące się przy poczcie. Nieruchomość tą nabyli oni od Lejby i Rajny Boruchowiczów za kwotę 550 złp $^{59}$. Z kolei w jeszcze innym przypadku do ksiąg miejskich wciągnięto dwa dokumenty dotyczące tej samej transakcji - mianowicie kontrakt kupna-sprzedaży nieruchomości oraz akt nadania tej samej posesji. Dnia 8 kwietnia 1772 r., batnik Józef Złotoszewski zakupił od Henryka i Karola Frydzów dom kryty dachówką wraz z placem i ogrodem za sumę 500 złp. Nieruchomość zlokalizowana była przy ul. Nowe Miasto, między posesjami Wojciecha Snycerza (po prawej stronie) oraz Wojciecha Złotoszewskiego (po lewej). Następnie do akt wpisano dokument nadania, w którym czytamy, że „mając wzgląd na zasługi Jana Złotoszewskiego i do dalszych zachęcając umyśliłem [Jan Klemens Branicki - przyp. M.K.] mu budynek na nowym mieście moim Białymstoku nadać". Następnie zostaje opisana ta sama nieruchomość. Hetman w dokumencie tym zobowiązał także Złotoszewskiego do przeznaczenia jednego z budynków, znajdujących się na niniejszej posesji, na mieszkanie dla innych batników ${ }^{60}$.

Właściciel miasta wpływał na rynek obrotu nieruchomościami nie tylko przez prawo udzielania zezwolenia na alienację, ale również sam skupował posesje. Serię takich transakcji zawarto przy ul. Wasilkowskiej, kiedy to w maju 1770 r. do ksiąg wciągnięto 7 takich wpisów. Branicki nabył wtedy nieruchomości leżące na prawej pierzei tej ulicy, głównie zaś puste parcele. $\mathrm{W}$ ten sposób zakupił on posesję Macieja i Zofii Skorców (domostwo z pla-

58 Z. Kaczmarczyk, B. Leśnodorski, Historia państwa i prawa Polski, t. 2: Od połowy XV wieku do r. 1795, Warszawa 1966, s. 304

59 AGAD, Archiwum Branickich z Białegostoku, sygn. 55, s. 6.

60 AGAD, Księgi miejskie białostockie, sygn. 2, s. 57-59. 
cem i ogrodem ${ }^{61}$ oraz Jana i Justyny Majewskich (domostwo z ogrodem) ${ }^{62}$. Hetman nabył również parcele Szymona i Marianny Dubiejko63, wdowy Zuzanny Haczkowskiej ${ }^{64}$ oraz Konstancji, żony Grzegorza Złotoszewskiego, która w czasie nieobecności męża sprzedała plac i ogród ${ }^{65}$. Również sukcesorzy Stefana Popławskiego (córki Marianna Olszewska, Rozalia Kryszyńska i Ludwika Johanowa) zbywają odziedziczoną nieruchomość66. Z kolei przy kontrakcie z małżeństwem Piekarskich, Branicki - mając wzgląd na podeszły wiek Kazimierza - pozwala mu postawić w tyle posesji niewielki budynek, który po śmierci małżonków należeć będzie do nowego posiadacza nieruchomości 67 .

Część transakcji między mieszkańcami Białegostoku odbywała się z woli właścicieli miasta. Przykładem takiej transakcji jest kontrakt zawarty między Konstancją, wdową po burmistrzu Janie Hołubowskim, a Markiem Szlomowiczem, który w czerwcu 1769 r. nabył plac z budynkiem skarbowym przy ul. Wasilkowskiej za kwotę 800 złp ${ }^{68}$. Zaś nieruchomość należąca do Ewy Kotulskiej i jej zięcia Jędrzeja Zakrzewskiego (mieszcząca się również przy ul. Wasilkowskiej) została z rozkazu dworu sprzedana złotnikowi nadwornemu Abramowi Konstantynowskiemu i jego żonie Frejdzie ${ }^{69}$. Podobnie Joachim Słonimski, z dyspozycji hetmana, zbył swoją posesję Janowi Sawickiemu $^{70}$.

Z zapisów tych wynika, że Branicki chciał uporządkować ul. Wasilkowską m.in. pod względem kwestii prawa własności posesji. Przede wszystkim zaś skupował on nieruchomości tam, gdzie właściciele nie byli wstanie ich utrzymać bądź odpowiednio zagospodarować. Hetman nabywał głównie niezabudowane parcele, zapewne by mieć możliwość postawienia tam budynków skarbowych, czy też, aby móc nadać je nowym posiadaczom. Świadczy o tym także fragment jednego z wpisów, gdzie czytamy, że „Pan nowo zabudować się wszystkim na ul. Wasilkowskiej kazał, a kto nie miał sposobu do budowania się, spłaciwszy takowych na skarb zabudowanie rozkazał"71.

61 Tamże, s. 32.

62 Tamże, s. 32-33.

63 Tamże.

64 Tamże, s. 30-31.

65 Tamże.

66 Tamże, s. 31-32.

67 Tamże, s. 33-34, 36-37.

68 Tamże, s. 22-23.

69 Tamże, s. 51-52.

70 Tamże, s. 35.

71 Tamże, s. 62. 
Podobne uregulowania miały również miejsce $\mathrm{w}$ innych częściach miasta. Jan Klemens Branicki angażował się w rozwój i rozbudowę Białegostoku. Jednym $\mathrm{z}$ jego działań $\mathrm{w}$ tej dziedzinie było podjęcie decyzji o zgrupowaniu browarów poza śródmieściem. Widomym tego śladem jest seria 8 transakcji z 1769 r., związanych z wykupem posesji zlokalizowanych przy późniejszej ul. Browarnej. Na życzenie hetmana dotychczasowi właściciele położonych tam nieruchomości, w większości chrześcijanie, mieli odsprzedać część swoich parceli izraelitom, z przeznaczeniem pod budowę browarów. Posesje te były niezabudowane, zostały dość regularnie wytyczone (liczyły po 14 sążni długości oraz od 3 do 5 szerokości), a ich położenie określono jako - „od parkanu Zwierzyńca"72. Analogiczne działania zmierzające do wyeliminowania obiektów przemysłowych poza obręb zabudowy podejmowano również w innych ośrodkach miejskich (przykładowo w Siemiatyczach Anna z Sapiehów Jabłonowska wydała zarządzenie, by browary budować na obrzeżach miasta ${ }^{73}$ ).

Braniccy na rynek nieruchomości mogli wpływać również przez nadania posesji. Tego typu darowizny dokonywane przez dziedzica były rzeczą typową, zwłaszcza gdy nieruchomości otrzymywały osoby związane bezpośrednio z właścicielem miasta, jako wynagrodzenie za zasługi, czy też długoletnią służbę. Jan Klemens Branicki w ten sposób uposażał swoich oddanych pracowników, artystów oraz oficerów wojskowych. Przedmiotem nadania były różnego rodzaju nieruchomości, takie jak: grunt, dom z ogrodem lub/i zabudowaniami gospodarczymi, a nawet austeria czy kamienica. Ze źródeł wynika również, że mieszczanie oraz magistrat pilnowali, aby poświadczenie takiego uposażenia było wciągane do ksiąg miejskich. W zachowanych trzech księgach oraz $\mathrm{w}$ wypisach $\mathrm{z}$ różnych dokumentów, mieszczących się w Archiwum Branickich z Białegostoku, Archiwum Roskim oraz tzw. tekach Jana Glinki, znajduje się kilkanaście aktów nadań nieruchomości.

Pierwsze nadania nieruchomości w Białymstoku odnotowano w latach trzydziestych XVIII stulecia ${ }^{74}$. Jednym $\mathrm{z}$ większych aktów tego typu było nadanie 1 lipca 1756 r. austerii Antoniemu Wroczyńskiemu75. Posiadał on wcześniej już jedną nieruchomość w mieście, także przy ul. Wasilkowskiej,

72 Tamże, s. 15-18, 21, 24-27.

73 A. Jabłonowska, Ustawy Powszechne Dla Dobr Moich Rządcow: Podług Exemplarza drukowanego przeszłego roku w Siemiatyczach za rozkazem J. O. Xiężny Jabłonowskiey, Woiewodziny Bracławskiey, t. 7, Warszawa 1787, s. 123

74 A. Sztachelska-Kokoczka, Białystok za pałacowa..., s. 120.

75 Archiwum Państwowe w Białymstoku (dalej: APB), Teki Glinki, teka 95, s. 25. 
którą sprzedał w 1745 r. ${ }^{76}$ Jedenaście lat później hetman przekazał mu dość pokaźny budynek, wydaje się więc, że był on lojalną oraz zaufaną osobą, co potwierdza również akt nominacja Wroczyńskiego z 1769 r. na landwójta Białegostoku.

W latach 1770-1772 można zaobserwować szereg nadań nieruchomości. Ich odbiorcami były osoby bezpośrednio związane $\mathrm{z}$ rezydencją hetmana, czyli urzędnicy dworscy, rzemieślnicy, artyści oraz służba. Przekazane im posesje znajdowały się przy ulicach: Wasilkowskiej, Zielonej, Choroskiej, Kleindorf oraz Nowe Miasto. Ta ostatnia ulica została stworzona przede wszystkim do obsługi pałacu, zatem była swoistym zapleczem dworu. Nie dziwi więc fakt, iż właśnie tam osiedlano nadwornych pracowników. W okresie tym (21 sierpnia 1770 r.) dom przy ul. Zielonej, wraz z ogrodem oraz zabudową gospodarczą (stodoła, szopa i chlew), otrzymał krawiec nadworny Józef Nowakowski. Branicki darował mu ten budynek w nagrodę za jego oddanie oraz zasługi, tym samym zachęcał go do dalszej służby. Ze szczegółowej treści wpisu wynika, iż nieruchomość ta należała wcześniej do Jakub Piątkowskiego. Jednakże był on zadłużony na kwotę w wysokości 1300 złp. Sumę tę spłacił hetman, za co przejął niniejszą posesję, a następnie nadał Nowakowskim ${ }^{77}$. Z kolei w $1770 \mathrm{r}$. Branicki przekazuje austerię przy ul. Bojarskiej cyrulikowi Włoskieczowi ${ }^{78}$. Ponadto, w listopadzie 1772 r. dom wraz z placem i stodołą przy ul. Choroskiej (naprzeciwko cerkwi unickiej) „w nagrodę pracowitych i pilnych usług" otrzymał komisarz nadworny Frantz Rotmann ${ }^{79}$. Tuż przed swoją śmiercią hetman zdążył dokonać jeszcze kilku nadań nieruchomości. Posesję na Nowym Mieście otrzymał waltornista z kapeli nadwornej Bernard Rotenberg ${ }^{80}$, zaś przy ul. Wasilkowskiej stelmach Jan Gotlib Krauze ${ }^{81}$. W czerwcu 1771 r. Jan Klemens Branicki nadał dwupiętrową kamienicę Bonifacemu Gromadzkiemu i jego żonie Mariannie z Kazimierskich, zwolnił ich również od ponoszenia wszelkich danin i czynszów na rzecz właściciela miasta ${ }^{82}$. Niestety, w tym ostatnim przypadku nie posiadamy informacji na temat tego, kim były tak hojnie obdarowane osoby oraz czym mogły się zasłużyć.

\footnotetext{
76 AGAD, Archiwum Roskie, Akta osobisto-rodzinne i majątkowo-prawne, sygn. 628, s. 1.

7 AGAD, Księgi miejskie białostockie, sygn. 2, s. 39-40.

78 APB, Teki Glinki, teka 125, s. 108.

79 AGAD, Księgi miejskie białostockie, sygn. 2, s. 43.

80 AGAD, Księgi miejskie białostockie, sygn. 3, s. 39-40.

81 AGAD, Archiwum Roskie, Akta osobisto-rodzinne i majątkowo-prawne, sygn. 628, s. 33

82 AGAD, Księgi miejskie białostockie, sygn. 3, s. 171-173.
} 
Po śmierci hetmana politykę wynagradzania swoich lojalnych i długoletnich pracowników kontynuowała Izabela z Poniatowskich Branicka. W przeciwieństwie do Jana Klemensa Branickiego, nie była ona właścicielką nadawanych nieruchomości, tylko dożywotnią posesorką ${ }^{83}$. Jednakże Branicka przekazała na własność część budynków skarbowych, co było niezgodne z ówcześnie obowiązującym prawem oraz stwarzało zobowiązania wobec spadkobierców po Janie Klemensie Branickim. Kwestię tę uregulowano dopiero w 1800 r. podczas ugody ze spadkobiercami, którzy w zamian za inne ustępstwa zgodzili się na zmianę stanu faktycznego $\mathrm{w}$ dobrach białostockich ${ }^{84}$. W 1773 r. Izabela Branicka nadała prawo na drewniane domostwo skarbowe, mieszczące się przy ul. Bojarskiej, szklarzowi Michałowi Hołubowiczowi ${ }^{85}$, podobnie uposażyła piwnicznego Józefa Pietrzykowskiego ${ }^{86}$ oraz stelmacha Pawła Kowalewskiego ${ }^{87}$. Analogicznych nadań było jeszcze kilka, jednak powyższe dane potwierdzają już wcześniej wspomnianą informację, iż odbiorcami donacji były osoby związane $\mathrm{z}$ dworem oraz samym hetmanem. Polityka wynagradzania swoich dworzan przez nadania nieruchomości była prowadzona nie tyko w Białymstoku Branickich. Można zaryzykować stwierdzenie, że właściciele większości miast prywatnych w ten sposób nagradzali swoich lojalnych współpracowników, bądź też osoby potrzebne z racji wykonywanego zawodu (np. rzemieślników).

Należy również wspomnieć o samej treści dokumentu nadania, która nie różni się niczym szczególnym od innych wpisów dotyczących zbycia lub przekazania własności. Czytamy w nich, iż dziedzic posesję „wiecznemi czasy nadaje, daje, daruje”. Dalej zaś pisano, że „wolne będzie komu chcąc $\mathrm{w}$ inne ręce przedawać, dać, darować lub zastawić, jednak za opowiedzeniem się dworu" ${ }^{88}$. Wynika stąd, iż właściciele miasta respektowali prawo mieszkańców do prywatnej własności, która była przedmiotem dziedziczenia i przechodziła na sukcesorów. Ponadto, osoba uposażona mogła tą nieruchomością swobodnie dysponować, jednakże musiało się to dziać za wiedzą i przyzwoleniem dworu. Nadaną posesję zbyła m.in. Dorota, wdowa po Bernardzie Rottenbergu (nieruchomość w 1773 r. za kwotę 400 złp nabył Jało-

83 Zob. K. Łopatecki, O instytucji dożywocia na przykładzie małżeństwa Jana Klemensa i Izabeli Branickich, „Krakowskie Studia z Historii Państwa i Prawa” 2016, t. 9, nr 1, s. 39-66.

84 K. Łopatecki, M. Kupczewska, Dyspozycje majątkowe Izabeli z Poniatowskich Branickiej na wypadek śmierci, „Kwartalnik Historii Kultury Materialnej” 2016, t. 64, nr 4, s. 486

85 AGAD, Księgi miejskie białostockie, sygn. 3, s. 38-39.

86 AGAD, Archiwum Roskie, Akta osobisto-rodzinne i majątkowo-prawne, sygn. 628, s. 37.

87 AGAD, Archiwum Branickich z Białegostoku, sygn. 48, s. 3.

88 AGAD, Księgi miejskie białostockie, sygn. 2, s. 59. 
wiecki) ${ }^{89}$. Z kolei w październiku 1785 r. sukcesorzy po landwójcie Antonim Wroczyńskim sprzedali odziedziczoną austerię małżeństwu Langierów ${ }^{90}$.

Należy także zwrócić uwagę, że zarówno Jan Klemens Branicki, jak i Izabela z Poniatowskich Branicka dążyli do stworzenia kompleksu prywatnych nieruchomości miejskich. Właściciele miasta czynili starania, aby nawet niezamożna osoba mogła nabyć dom skarbowy. Przykłady takiego działania znajdujemy w korespondencji Wojciecha Matuszewica (podskarbi białostocki) do Izabeli Branickiej. W 1776 r. pisał on, że gdy Jerzy Szewc Moskal odrobi do skarbu 200 złp, to otrzyma prawo na budynek skarbowy, w którym aktualnie mieszka ${ }^{91}$.

Przytoczone wpisy ukazują duże zainteresowanie oraz ingerencję właścicieli Białegostoku we wszystkie aspekty życia w mieście. Wydaje się, że oddziaływanie hetmana na rynek nieruchomości było częścią jego świadomej polityki w tym względzie. Mimo to Braniccy szanowali prawo mieszczan do ich własności. Magistrat oraz sami mieszkańcy Białegostoku dbali o to, aby poświadczenia wszystkich transakcji był wciągane do ksiąg miejskich. Świadczą o tym liczne transakcje kupna-sprzedaży, w których uczestniczyła zarówno ludność o polsko brzmiących nazwiskach (86\% sprzedających oraz $47 \%$ kupujących), ale także i Żydzi (stanowili 6\% zbywców oraz $42 \%$ nabywców posesje). Białostocki rynek obrotu nieruchomościami charakteryzował się jednokrotną obecnością osób w nim uczestniczących. Przeciętny mieszkaniec miasta tylko sprzedawał bądź kupował nieruchomość, występując po jednej stronie rynku. Częstym przedmiotem transakcji były drewniane domy ( $42 \%$ wszystkich kontraktów), chętnie kupowano również puste parcele (37\% aktów kupna-sprzedaży). Margines obrotów stanowił zaś handel ziemią rolną (jedynie 8\% wpisów). Ceny nieruchomości były bardzo różne, kształtowały się zaś w zależności od rodzaju posesji oraz jej lokalizacji przestrzennej. $Z$ kolei termin zawarcia umowy kupna-sprzedaży nieruchomości przypadał przede wszystkim na okres wiosenny - $\mathrm{w}$ terminie od marca do czerwca do ksiąg wpisano aż 61,5\% wszystkich transakcji. Analiza wykazała również znaczy wzrost zapisów na początku lat siedemdziesiątych XVIII stulecia.

89 AGAD, Księgi miejskie białostockie, sygn. 3, s. 39.

90 AGAD, Księgi miejskie białostockie, sygn. 2, s. 85-87.

91 AGAD, Archiwum Roskie, Korespondencja, sygn. 65/1, k. 35. 
Zachowane $\mathrm{w}$ księgach miejskich wpisy, mimo że dotyczą części reaInie przeprowadzonych transakcji, pozwalają na przeprowadzenie analizy kondycji ekonomicznej białostockich mieszczan. Dzięki zastosowaniu metod kwantytatywnych możliwe staje się ukazanie struktury i skali obrotów. Pełna ocena poziomu życia gospodarczego badanego ośrodka wymaga jednak rozwinięcia studiów komparatystycznych, których zdecydowanie brakuje także w przypadku innych miast historycznego Podlasia.

\section{Bibliografia}

\section{Źródła archiwalne}

Archiwum Główne Akt Dawnych:

Archiwum Branickich z Białegostoku, sygn. 48, 55.

Archiwum Roskie, Akta osobisto-rodzinne i majątkowo-prawne, sygn. 628.

Archiwum Roskie, Korespondencja, sygn. 65/1.

Księgi miejskie białostockie, sygn. 1-3.

Archiwum Państwowe w Białymstoku:

Teki Glinki, teka 95, 108.

\section{Źródła drukowane}

Jabłonowska A., Ustawy Powszechne Dla Dobr Moich Rządcow: Podług Exemplarza drukowanego przeszłego roku w Siemiatyczach za rozkazem J. O. Xiężny Jabłonowskiey, Woiewodziny Bracławskiey, t. 7, Warszawa 1787.

Pałac Branickich w Białymstoku, t. 2: Lata 1802-1809, oprac. K. Łopatecki, W. Walczak, Białystok 2015.

Pruskie opisy miast polskich z końca XVIII wieku: departament białostocki, oprac. J. Wąsicki, Poznań 1964.

Spisy mieszkańców Białegostoku z lat 1799-1853, oprac. W. Wróbel, Białystok 2016.

\section{Opracowania}

Barylewska-Szymańska E., Gdański rynek nieruchomości w latach 1770-1776, [w:] Dom w mieście średniowiecznym i nowożytnym, red. B. Gediga, Wrocław 2004, s. 287$-297$.

Bukowska K., Orzecznictwo krakowskich sąów wyższych w sporach o nieruchomości miejskie (XVI-XVIII w.), Warszawa 1967.

Czyżewski P., Gospodarka Wasilkowa - miasteczka pogranicza Korony i Litwy - w XVI-XVIII wieku, [w:] Małe miasta. Gospodarka, red. M. Zemło, Lublin-Supraśl 2007, s. $35-84$.

Dobroński A.Cz., Białystok w latach 1796-1864, [w:] Historia Białegostoku, red. A.Cz. Dobroński, Białystok 2012, s. 213-280. 
Hanejko E., Miasto w okresie od wielkiego sporu o Ordynacje do I rozbioru Polski, [w:] Tomaszów Lubelski: monografia miasta, red. R. Szczygieł, Lublin-Tomaszów Lubelski 2011, s. 127-215.

Kaczmarczyk Z., Leśnodorski B., Historia państwa i prawa Polski, t. 2: Od połowy XV wieku do r. 1795, Warszawa 1966.

Kupczewska M., Łopatecki K., Testament Izabeli z Poniatowskich Branickiej (3 XI 1805), „Kwartalnik Historii Kultury Materialnej” 2016, t. 64, nr 1, s. 103-119.

Łopatecki K., Kupczewska M., Dyspozycje majatkowe Izabeli z Poniatowskich Branickiej na wypadek śmierci, „Kwartalnik Historii Kultury Materialnej” 2016, 64, 4, s. $485-493$.

Łopatecki K., O instytucji dożywocia na przykładzie małżństwa Jana Klemensa i Izabeli Branickich, „Krakowskie Studia z Historii Państwa i Prawa” 2016, 9, 1, s. 39-66

Łopatecki K., Sprzedaż dóbr białostockich przez spadkobierców Jana Klemensa Branickiego, „Studia Podlaskie” 2015, nr 23, s. 75-99.

Łopatecki K., Ustrój XVIII-wiecznego miasta Białystok, „Miscellanea Historico-Iuridica” 2015 , t. 14 , z. 1, s. 349-379.

Łozowski P., Rynek nieruchomości w Starej Warszawie w latach 1427-1453, „Klio. Czasopismo poświęcone dziejom Polski i powszechnym" 2016, t. 39, nr 4, s. 47-76.

Makowska A., Prywatne miasto Staszów i dobra staszowskie, Warszawa 1981.

Małek A., Mieszkańcy Białegostoku pod zaborem pruskim, „Zeszyt Naukowy Muzeum Wojska" 1996, 10, s. 55-142.

Mycio A., Zadłużenie hipoteczne i obrót nieruchomości w Starym Mieście Toruniu w pierwszej połowie XVII w., Torun 2003.

Obrót nieruchomościami na ziemiach polskich od średniowiecza do XX wieku, red. F. Kusiak, Poznań-Wrocław 2008

Oleksicki A., Socjotopografia Białegostoku w XVIII w. w świetle inwentarza miasta z 1771/72 i planu Beckera z 1799 r., [w:] Studia i materiały do dziejów miasta Białegostoku, red. H. Majecki, t. 4, Białystok 1985, s. 41-56.

Oleksicki A., Zabytki architektury w Siemiatyczach a przemiany w przestrzennym rozplanowaniu miasta w XVIII w., [w:] Studia i materiały do dziejów Siemiatycz, red. H. Majecki, Warszawa 1989, s. 43-49.

Opas T., Własność w miastach i jurydykach prywatnych w dawnej Polsce: studium historyczno-prawne, Lublin 1990.

Rajman J., O cenach nieruchomości w średniowiecznym Krakowie, „Teka Komisji Urbanistyki i Architektury" 1990, nr 24, s. 7-13.

Sztachelska A., Białostocki ośrodek miejski w okresie działalności Jana Klemensa Branickiego. Zagadnienia prawno-ustrojowe, sadownictwo i zabudowa miasta, [w:] Studia i materiaty do dziejów miasta Białegostoku, red. H. Majecki, t. 4, Białystok 1985, s. 71-82.

Sztachelska-Kokoczka A., Biatystok w czasach Branickich (lata 1708-1795), [w:] Historia Białegostoku, red. A.Cz. Dobroński, Białystok 2012, s. 97-179.

Sztachelska-Kokoczka A., Białystok za pałacowq brama, Białystok 2009. 
Sztachelska-Kokoczka A., Obrót nieruchomościami miejskimi na terenie Białegostoku w XVIII w., „Białostocczyzna” 1992, t. 28, nr 4, s. 6-9.

Wiśniewski T., Cmentarze żydowskie w Białymstoku, „Studia Podlaskie” 1989, nr 2, s. 380-396.

Zielińska T., Szlacheccy właściciele nieruchomości w miastach XVIII w., Warszawa 1987.

\section{The real estate market in Bialystok in the 18th century}

\section{Summary}

The article presents the outcomes of the analysis of the real estate market's operation in Bialystok in the second half of the 18th century. The research has been based on the oldest preserved Bialystok city records from 1740-1795, where 97 contracts of purchase and sale have been found (mainly of houses and empty plots). The following elements have been explored: a structure of entries, a scale of sales, real estates' prices and types, and a social structure of purchasers and sellers (market share represented by Christians, Jews and women). The analyzed entries confirm Bialystok owners' high interest and commitment to the real estate market. What is more, the analysis revealed a considerable increase in the entries at the beginning of the 1770s.

Monika Kozłowska - historyk, doktorantka w Instytucie Historii i Nauk Politycznych Uniwersytetu w Białymstoku; główne zainteresowania badawcze: historia społeczno-gospodarcza. Przygotowuje rozprawę doktorską podejmującą problematykę wpływu zmian klimatu na gospodarkę Rzeczypospolitej przedrozbiorowej, ze szczególnym uwzględnieniem okresu tzw. Małej Epoki Lodowcowej.

e-mail: mkozlowska92@o2.pl 